\title{
IMPACT OF POST-HARVEST PROCESSING AND STORING OF POTATO TUBERS ON TOXIC COMPOUNDS ACCUMULATION
}

\author{
Magdalena Dusza ${ }^{a^{*}}$, Maciej Sporysz ${ }^{\mathrm{b}}$, Dorota Sokołowska ${ }^{\mathrm{c}}$, Katarzyna Grotkiewicz ${ }^{\mathrm{d}}$ \\ a Department of Agrobiotechnology, Koszalin University of Technology, Racławicka 15-17, 75-620 \\ Koszalin, Poland e-mail: 92.m.stanek@gmail.com \\ b Department of Production Engineering, Logistics and Applied Computer Science, University of \\ Agriculture in Krakow, Krakow, Poland e-mail: maciej.sporysz@urk.edu.pl, ORCID 0000-0003- \\ 4192-7235 \\ c Department of Agrobiotechnology, Koszalin University of Technology, Racławicka 15-17, 75-620 \\ Koszalin, Poland e-mail: dorota.sokolowska91@wp.pl, ORCID 0000-0002-0989-2477 \\ d Department of Production Engineering, Logistics and Applied Informatics, University of Agriculture \\ in Krakow, katarzyna.grotkiewicz@urk.edu.pl, ORCID 0000-0001-8564-0928 \\ *Corresponding author: e-mail: 92.m.stanek@gmail.com
}

\begin{tabular}{|c|c|}
\hline ARTICLE INFO & ABSTRACT \\
\hline $\begin{array}{l}\text { Article history: } \\
\text { Received: April } 2020 \\
\text { Received in the revised form: } \\
\text { May } 2020 \\
\text { Accepted: May2020 }\end{array}$ & $\begin{array}{l}\text { Despite a long-term reduction trend, the potato production in Poland } \\
\text { compared to EU countries is still very high. Therefore, the aim of the } \\
\text { paper was to investigate the impact of mechanical damages and light } \\
\text { for various genotypes on glycoalkaloids accumulation. Glycoalkaloids } \\
\text { are toxic steroid glycosides that naturally occur in the family of Sola- }\end{array}$ \\
\hline $\begin{array}{l}\text { Key words: } \\
\text { mechanical damage of tubers, } \\
\text { impact of light on tubers, } \\
\text { storage of tubers }\end{array}$ & $\begin{array}{l}\text { naceae. According to many authors, their presence in plants is related } \\
\text { to resistance to a physiological stress inflicted by mechanical damages } \\
\text { and infections caused by some microorganisms and insects. The TGA } \\
\text { content above } 200 \mathrm{mg} \cdot \mathrm{kg}^{-1} \text { in a fresh mass of potatoes is an upper limit } \\
\text { that guarantees health safety of food. Studies were carried out on } 28 \\
\text { potato cultivars divided into } 4 \text { groups. The studies that were carried out } \\
\text { after harvesting and after } 5 \text { months of storage in the experimental stor- } \\
\text { age room in the temperature of } 8^{\circ} \mathrm{C} \text { showed an impact of damages and } \\
\text { exposition to light of potato tubers on the content of glycoalkaloids. }\end{array}$ \\
\hline
\end{tabular}

\section{Introduction}

Total Glyco Alkaloids (TGA) Are toxic nitrogen steroid glycosides which naturally occur in plants of Solanaceae family. They are mainly represented by $\alpha$-chaconine $(60 \%)$ and $\alpha$ - solanine (40\%), which are commonly called solanine (D’Mello, 1997; Friedman and Mc Donald, 1997; Friedman, 1992). Presence of these compounds was found in potato leaves, stems, flowers, and tubers (Kumar et al., 2017). These substances increase the resistance of plants to bacterial and fungi diseases and some pests. This activity, however, has not been clearly confirmed (Friedman and Mc Donald, 1997; Friedman, 1992).

The content of glycoalkaloids in tubers exceeding $140 \mathrm{mg} \cdot \mathrm{kg}^{-1}$ of fresh mass included deterioration of the potato taste - a bitter taste has been confirmed (Friedman and Mc Donald, 
1997). TGA concentrate usually in the potato skin or just beneath it, therefore removal of the skin considerably reduces their content (even to 90\%). It has a great meaning in human feeding since consumption of potatoes with glycoalkaloids may cause damage to the digestive tract and nervous system. The symptoms of poisoning include throat irritation, stomach pains, nausea, vomiting, diarrhoea, weakening and neurological problems (D'Mello, 1997; Percival, 1999; Zgórska et al. 2006). In majority of the European Countries, including Poland, a safe content of glycoalkaloids in potato tubers was assumed as the amount of $100 \mathrm{mg} \cdot \mathrm{kg}^{-1}$ of fresh mass.

The current studies proved that the content of glycoalkaloids in tubers is preconditioned with genetic factors (cultivar) (Olsson, 1986) and environmental ones such as e.g. a place of cultivation, degree of maturity, size of tubers and fertilization. The main factors which influence the synthesis of these compounds in mature tubers after harvesting are mechanical damages to which tubers are exposed during harvesting and sorting (Nie at al., 2019; FrydeckaMazurczyk and Zgórska, 1999; Zgórska et al., 2006), Among others climate, environment, temperature and storage time influence the glycoalkaloids synthesis to a lesser degree (Griffiths, 1997; Papathanasiou et al., 1999).

The objective of the paper was to investigate the impact of mechanical damages and light for various genotypes on accumulation of glycoalkaloids.

\section{Material and research methods}

28 potato cultivars of various groups of maturity were a research material ( 9 very early cultivars, 7 early, 5 average early, 7 average late cultivars). The content of glycoalkaloids in tubers was determined shortly after harvesting and after 5 months of storage in the experimental storage room in the temperature of $8^{\circ} \mathrm{C}$. Tubers were subjected to mechanical loads in the mechanical rotational drum (causing damages similar to the ones that occur on the sorting line) and a week-long light exposition under $15 \mathrm{~W}$ with a fluorescent lamp that simulates a supermarket lighting (density of photons stream $13 \mu \mathrm{mol} \mathrm{m}{ }^{-2} \cdot \mathrm{s}^{-1}$ ). The content of glycoalkaloids was determined with a spectrophotometric method with ortho-phosphoric acid (Bergers, 1980). The impact of the investigated factors was determined with the use of F Snedecor test for the fixed model.

\section{Results and discussion}

The studies present the impact of the genotype on the glycoalkaloids accumulation caused by mechanical damage and light. Experimental results were set in table 1.

The investigated cultivars differed with the glycoalkaloids content in tubers after harvesting. Levels of these compounds in tubers were from $41.75 \mathrm{mg} \cdot \mathrm{kg}^{-1}$ for very early cultivars to $59.70 \mathrm{mg} \cdot \mathrm{kg}^{-1}$ for mid/early cultivars. The analysis of the impact of damages and cultivars on the glycoalkaloids content was presented in figure 1 . 
Impact of post-harvest...

Table 1.

Glycoalkaloids content ( $\mathrm{mg}^{\mathrm{kg}} \mathrm{k}^{-1}$ of fresh mass) after harvesting and after 5 months of storage

\begin{tabular}{|c|c|c|c|c|c|c|c|c|}
\hline \multirow[b]{2}{*}{ Cultivars } & \multicolumn{4}{|c|}{$\begin{array}{l}\text { Tubers after } \\
\text { harvesting }\end{array}$} & \multicolumn{4}{|c|}{$\begin{array}{l}\text { Tubers after } 5 \text { months } \\
\text { of storage in } 8^{\circ} \mathrm{C}\end{array}$} \\
\hline & 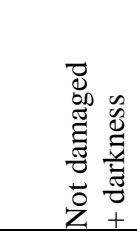 & 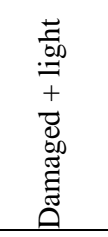 & 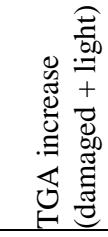 & 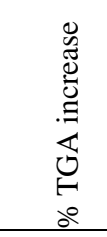 & 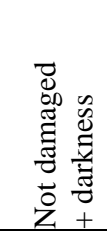 & 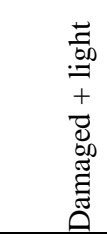 & 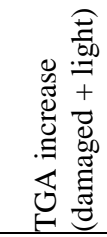 & 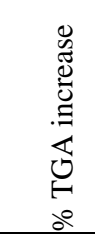 \\
\hline Very early & 41.75 & 96.00 & 54.25 & 129.94 & 51.25 & 121.25 & 70.00 & 136.59 \\
\hline Early & 45.33 & 96.00 & 50.67 & 111.78 & 49.66 & 119.00 & 69.34 & 139.63 \\
\hline Mid/early & 59.70 & 138.10 & 78.40 & 131.32 & 65.30 & 159.20 & 93.90 & 143.80 \\
\hline Mid/late & 46.88 & 101.00 & 54.12 & 115.44 & 51.63 & 126.50 & 74.87 & 145.01 \\
\hline
\end{tabular}

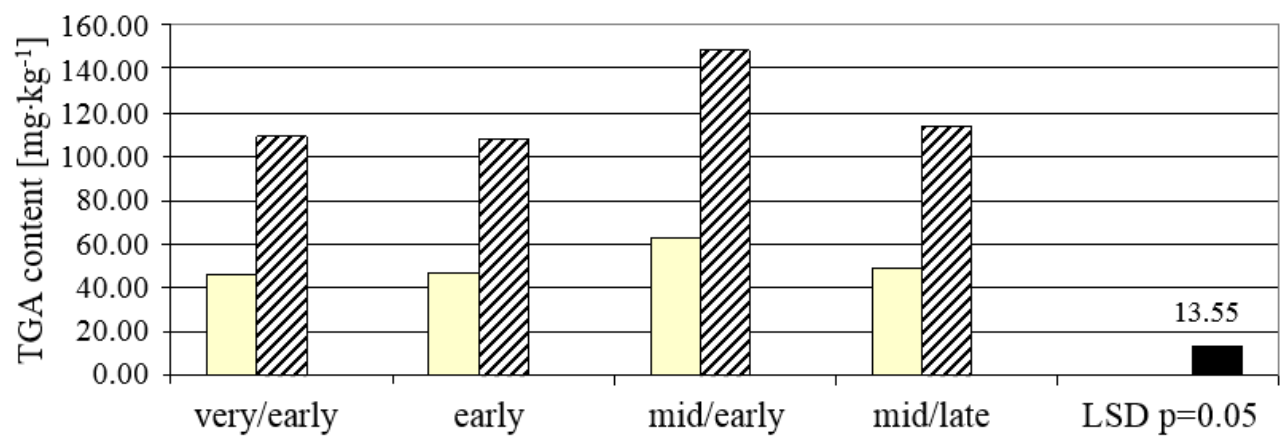

Group of cultivars

$\square$ not damaged + darkness $\quad \square$ damaged + light $\quad$ LSD $p=0.05$

Figure 1. Impact of damages and cultivars on the glycoalkaloids content in potato tubers

Under the influence of mechanical damage and a week-long exposure to light, the content of toxic compounds increased to over $100 \%$ in all investigated cultivars. The highest increase was observed in case of mid/early cultivars $(131.32 \%)$ after harvesting. The TGA content in those cultivars exceeded $150 \mathrm{mg} \cdot \mathrm{kg}^{-1}$. Discussions on the safety recommend that the level of those anti-nutritional compounds in edible potato tubers was higher than $100 \mathrm{mg} \cdot \mathrm{kg}^{-1}$ of fresh mass (Friedman and Mc Donald, 1997). Such a considerable increase of the glycoalkaloids content in tubers is confirmed also by such research results of other authors (Dale et al., 1993). However, serious damages, that cause crushing and smashing of tubers are responsible for initiation of the synthesis of glycoalkaloids to a much higher degree (external damage) 
(D’Mello, 1997). On the other hand, according to Dale et al. (1993), internal damages cause a serious increase in the content of chlorogenic acid and glycoalkaloids even by $130 \%$.

The glycoalkaloids content in tubers is preconditioned by genetic and environmental factors, i.e. maturity of tubers, mechanical damage, weather conditions during vegetation and temperature of storage (Griffiths et al., 1994; Frydecka-Mazurczyk and Zgórska, 1995). Potato tubers after harvesting should have possibly the lowest content of these compounds since under the influence of stress caused by light and mechanical damages, a sudden increase of these components in tubers takes place Dale et al., 1993; Frydecka-Mazurczyk and Zgórska, 2001; Percival and Dixon, 1996). Figure 2 presents an impact of the stress factors and storage on accumulation of glycoalkaloids in tubers of the tested cultivars.

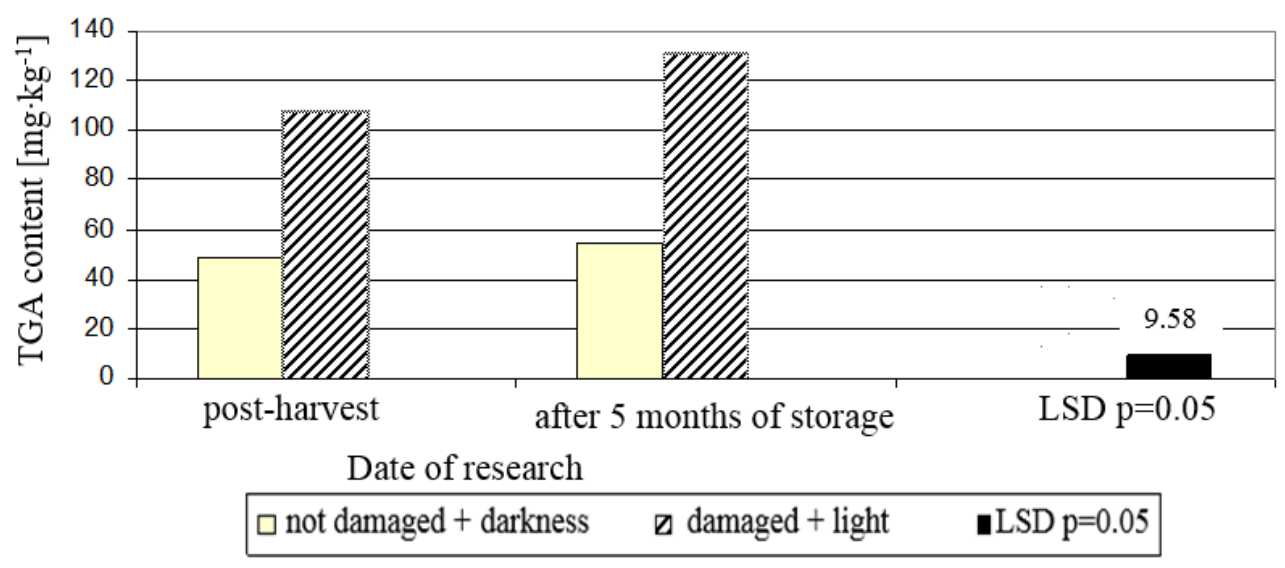

Figure 2. Impact of damages and storage on the glycoalkaloids content in potato tubers.

Based on the studies it was concluded that during storage the glycoalkaloids content in tubers increased and stress factors caused an additional increase of this content. In all the investigated potato tubers an increase of the glycoalkaloids content after 5 months of storage in the temperature of $8^{\circ} \mathrm{C}$ was reported, however it was the lowest in case of early cultivars. Mechanical damages and exposure to light influences the accumulation of those toxic compounds in tubers. The highest percentage of the TGA increase was reported in tubers of average late cultivars (145.01\%). However, the glycoalkaloids content in the group of average early cultivars was at the highest level which was similar to the limit that guarantees food health safety. TGA accumulation could have been influenced by not only a cultivar or the storage time but also temperature of storage. Since, it was found out that a high storage temperature $\left(8^{\circ} \mathrm{C}\right)$ limits the content of reducing sugars, however, after the storage, deterioration of the tubers quality caused by the loss of turgor and increase of the glycoalkaloids content as a result of biochemical shifts related to germination and the processed of ageing of tubers is observed (Zgórska and Sowa-Niedziałkowska, 2005).

In consumption purposes before sale, it is recommended to separate tubers with more serious damages from the rest of the batch. A type of the caused damages and their effect that shows in the increase of the TGA concentration is a constantly discussed issue by farmers 
Impact of post-harvest...

and sellers. It is significant to minimize the light exposure and sources of damage to potato tubers during the production process.

\section{Conclusions}

The studies that were carried out showed an impact of damage and exposure to light of potato tubers on the glycoalkaloids content. Based on the obtained results, the following conclusions can be made:

1. Mechanical damage and exposure to light influenced the increase of synthesis of glycoalkaloids in tubers.

2. Tubers of early cultivars had a lower ability to accumulate these compounds caused by stress factors.

3. The storage time influenced the increased TGA concentration in tubers of the investigated cultivars.

4. The highest concentration of glycoalkaloids was is case of mid/ late tubers stored for 5 months in the temperature of $8^{\circ} \mathrm{C}$.

\section{References}

Bergers, W. (1980). A rapid quantitative assay for solanidyne glycoalkaloids in potatoes and industrial potato protein. Potato Research, 23, 105-110.

D’Mello, J.P. (1997). Plant and Fungal toxicans. Glycoalkaloids. Boca Ranton, New York, 19-35.

Dale, M.F.B., Griffiths, D.W., Todd, D. (1993). Glycoalkaloid increase in Solanum tuberosum on exposure to light. Annals of Applied Biology, 123, 411-418.

De Maine, M.J., Bain H., Joyce J.A.L. (1988). Changes in the total tuber glycoalkaloid content of potato cultivars on exposure to light. Journal of Agricultural Science, 111, 57-58.

Friedman, M. (1992). Composition and safety evaluation of Potato berries. Potato and Tomato seeds, Potatoes and Potato Alkaloids. American Chemical Society, 35, 429-462.

Friedman, M., Mc Donald, G.M., Filadelfi-Keszi, M. (1997). Potato glycoalkaloids chemistry, analysis, safety and plant physiology. Critical Reviews in Plant Sciences, 16, 55-132.

Frydecka-Mazurczyk, A., Zgórska, K. (2001). The influence of genotype on the effects of impact damage and light exposure on the accumulation of glycoalkaloids in potato tubers. Roczniki Państwowego Zaktadu Higieny, 52, 139.-144

Frydecka-Mazurczyk, A., Zgórska, K. (1995). Nitrate and glycoalkaloids concentration and potato tubers during the vegetation and storage period. Joint Meeting Agronomy and Utilization Sections of EAPR. Abstract of papers, Vila Real, Portugalia, 50-51.

Frydecka-Mazurczyk, A., Zgórska, K. (1999). Wpływ stresu wywołanego działaniem światła i uszkodzeń mechanicznych na akumulację glikoalkaloidów w bulwach ziemniaka. Zeszyty Problemowe Postępów Nauk Rolniczych, 469, 285-292.

Griffiths, D.W., Bain, H., Dale, M.F.B. (1994). The effect of cultivar, maturity and storage on photoinduced changes in the total glycoalkaloid and chlorophyll contents of potatoes. Plant Science, 98, 103-109.

Griffiths, D.W., Bain, H., Dale, M.F.B. (1997). The effect of low- temperature storage on the glycoalkaloid content of potato tubers. Journal of the Science of Food and Agriculture, 74, 301-307.

Kumar, A., Fogelman, E., Weissberg, M., Tanami, Z., Veilleux, R.E. \& Ginzberg, I. (2017). Lanosterol synthase-like is involved with differential accumulation of steroidal glycoalkaloids in potato. Planta, 246, 1189-1202. 
Nie, X., Li, C., Zhang, G., Shao, Z., Wang, X., Shi, H., Guo, H. (2019). Light exposure and wounding: synergistic effects on steroidal glycoalkaloid accumulation in potato tubers during storage. International Journal of Food Science and Technology, 54, 2939-2948.

Olsson, K. (1986). The influence of genotype on the effect of impact damage on accumulation of glycoalkaloids in potato tubers. Potato Research, 29, 1-12.

Papathanasiou, F., Mitchell, S., Watson, S., Harvey, B.M.R. (1999). Effect of environmental stress during tuber development on accumulation of glycoalkaloids in potato. Journal of the Science of Food and Agriculture, 79, 1183-1189.

Percival, G.C. (1996). Glycoalkaloid concentration of potato tubers following exposure to daylight. Journal of the Science of Food and Agriculture, 71, 59-63.

Percival, G.C. (1999). The influence of light upon glycoalkaloid and chlorophyll accumulation in potato tuber. Plant Science, 145, 99-107.

Zgórska, K., Czerko, Z., Grudzińska, M. (2006). Wpływ wybranych czynników na zawartość glikoalkaloidów w bulwach ziemniaka. Żywność Nauka Technologia Jakość, 1(46), 229-234.

Zgórska, K., Sowa-Niedziałkowska, G. (2005). Wpływ czynnika termicznego i odmianowego na zmiany jakościowe zachodzące w bulwach ziemniaka w czasie ich długotrwałego przechowywania. Pamiętnik Pulawski, 139, 327-336.

\title{
WPLYW OBRÓBKI POZBIOROWEJ I PRZECHOWYWANIA BULW ZIEMNIAKA NA AKUMULACJE TOKSYCZNYCH ZWIĄZKÓW
}

\begin{abstract}
Streszczenie. Mimo wieloletniego trendu spadkowego, produkcja ziemniaków w Polsce jest, na tle krajów UE, w dalszym ciągu bardzo wysoka, dlatego celem pracy było zbadanie wpływu uszkodzeń mechanicznych i działania światła dla różnych genotypów na akumulację glikoalkaloidów. Glikoalkaloidy są toksycznymi glikozydami sterydowymi naturalnie występującymi w rodzinie Solanacea. Zdaniem wielu autorów ich obecność $\mathrm{w}$ roślinach wiąże się z odpornością na stres fizjologiczny wywołany uszkodzeniami mechanicznymi oraz infekcjami spowodowanymi przez niektóre mikroorganizmy i owady. Zawartość TGA powyżej $200 \mathrm{mg} / \mathrm{kg} \mathrm{w}$ świeżej masie ziemniaków stanowi górną granicę gwarantującą bezpieczeństwo zdrowotne żywności. Badania przeprowadzono na 28 odmianach ziemniaka podzielonych na 4 grupy. Badania przeprowadzone po zbiorze i po 5 miesiącach przechowywania w przechowalni doświadczalnej w temperaturze $8^{\circ} \mathrm{C}$ wykazały wpływ uszkodzeń i ekspozycji na światło bulw ziemniaka na zawartość glikoalkaloidów.
\end{abstract}

Słowa kluczowe: uszkodzenia mechaniczne bulw, działanie światła na bulwy, przechowywanie bulw 